\title{
Transfusion of a Patient with An auto-immune Hemolytic Anemia, After Screening by The Test Tube Method in a low Resource Setting
}

\author{
Sankalp Sharma*, Ajay Yadav and Santosh T \\ Department of Transfusion Medicine and Blood Bank, All India Institute of Medical Sciences, Raipur, India
}

\begin{abstract}
A six year male was diagnosed with right sided pneumonia and pleural effusion and a clinical presentation of autoimmune hemolytic anemia. The blood sample to the blood center showed auto-agglutination in the EDTA vacutainer. Blood grouping and cross-matching had an objective of transfusing the most compatible blood unit to this patient, in a setting of a low resource Blood storage center of a new tertiarycare establishment.
\end{abstract}

Keywords: Autoimmune Hemolytic Anemia, Thermal reactivity, Cold Agglutinin Disease

\section{Introduction}

Cold Agglutinin Diseases are classified as primary and secondary types which are responsible for the formation of clinically significant antibodies; responsible for in vivo RBC hemolysis of the patient. ${ }^{[1]}$ The blood banker has an option of providing an antigen negative blood to such patient after the detection and removal of autoantibodies with autologous RBCs and/or segregation of alloantibodies by techniques involving adsorption followed by alloantibody identification with the select allogenic RBCs or commercial antiserum. ${ }^{[2,3]}$ Specialised techniques have been described such as pre-warming for a select removal of auto-antibodies and unmasking of clinically significant allo-antibodies. ${ }^{[2,4]}$ Pre-warming technique involves warming separately the saline suspended RBCs and serum at $37^{\circ}$ Celsius to detect the antibody activity at $37^{\circ} \mathrm{C}$ after the cells and serum are reacted under ambient conditions. ${ }^{[2,4]}$ The technique though useful in the detection of clinically significant antibody can be less sensitive and non-specific in the absence of potentiators like the low ionic salt solution (LISS) or polyethylene glycol (PEG) or reagents enzymes such as papain and ficin to destroy the antigenic sites of the clinically irrelevent antibodies..$^{[2,3,4]}$

The present case involves a child with auto-agglutination of RBCs and rapid development of clinically significant anemia.

\section{Case Report}

A six year old male; was admitted with complain of cough, fever and respiratory distress for 10 days. On examination this patient had signs of respiratory distress with features of pneumonic effusion involving lower lobes of lungs. Patient had a positive family history of tubercular pleural effusion involving the child's father. A provisional diagnosis of pneumonia with effusion (?empyema ) was made and the patient was kept on continuous partial airway pressure with oxygen. A diagnostic pleurocentesis revealed hemorrhagic effusion with cytology revealing total cell count of $1500 /$ cumm and neutrophil predominance. This patient subsequently developed a non-pruritic macular rash on the arms and legs. A possibility of drug reaction to ampicillin was considered. The serological investigations for HIV 1, 2, Malaria and Dengue were negative. Serum Antinuclear antibody titer was positive with a titer of 1:160.Prothrombin time was 17.6 (normal 12.4-15.2) with INR value of 1.18 (normal 0.8-1.2).Liver function tests showed Gamma Glutamyl transferase value of 90 (normal 9-55).A culture sensitivity of the pleural fluid after 48 hours of incubation was negative with adenosine Deaminase (ADA) level 86.5 (normal 0.00 -36.00). Blood culture was negative after 24 hours and 7 days. Serum lactate dehydrogenase level on day 3 was 2773 (normal 85-27).Urine culture sensitivity was sterile with normal microscopic findings. Peripheral smear findings showed morphology suggestive of red cell agglutination with a mild shift to the left of the myeloid series and occasional reactive lymphocytes.

Patient was started on an Anti-tubercular treatment on the day 11 of admission. A clinically increasing pallor in patient and hemoglobin, hematocrit and platelet values of the patient showed progression.with hemoglobin levels on the day 10 showing a drop to $3.3 \mathrm{~g} / \mathrm{dl}$. Blood bank was requested for a transfusion of one unit of red cell concentrate in this patient having clinically increasing pallor and persistent fever with tachycardia.

Blood sample received at the blood center in plain and EDTA vacutte showed clots on physical examination of the 
EDTA vacutte. Two different samples in EDTA vacutainer were evaluated for blood grouping, with a visible clotting in both the samples. The objective of most compatible blood for transfusion for the blood grouping and crossmatching according to the thermal range of reactivity of the patient antibody was followed and antibody screening of the patients serum by an indirect Agglutination Testing (complete cross matching) using the test-tube method.

The objectives and the steps of progression were listed as follows.

To find out the thermal amplitude of minimum antibody reactivity,

To release the blood unit showing minimum reactivity with the patient blood sample by a complete cross-match.

The sample was divided into three parts for the preparation of 3\% Red Cell suspension and evaluated for blood grouping, cross-matching and antihuman globulin tests at $4^{\circ} \mathrm{C} ; 37^{\circ} \mathrm{C}$ and room temperature at $24^{\circ} \mathrm{Celsius}$.Sample kept at $37^{\circ} \mathrm{C}$ showed loss of agglutination in the $3 \%$ red cell suspension and the forward grouping for red cells was B positive. Reverse grouping showed a mixed field reaction with the pooled B cells and O cells respectively. Sample at $4^{\circ} \mathrm{C}$ and $24^{\circ} \mathrm{C}$ showed the forward and reverse grouping as shown in the Table 1.

Auto-control of patient cells with the patient serum showed agglutination in all the three temperature range and with only microscopic agglutination at $37^{\circ}$ celsius (Table 2). Patient cells with Bovine serum albumin (negative control for a reaction of patient cells with patient serum) however did not show RBC agglutination. The cross-match was performed against two units of $\mathrm{B}$ positive packed RBCs. The major cross-match was incompatible at $4^{\circ} \mathrm{C}$ and $24^{\circ} \mathrm{C}$ and compatible at $37^{\circ} \mathrm{C}$ indicating that the antibody was non-agglutinating at body temperature. The most compatible unit was used for transfusion of this patient Table 1 .

The blood transfusion was advised under a steroid cover to be transfused slowly with pre- transfusion baseline parameters, monitoring of the patient in course of transfusion and the post-transfusion parameters $(15 \mathrm{~min}$, post-transfusion and 24 hours respectively).

Patient was transfused after checking the vitals and 60-70 $\mathrm{ml}$ of Red-cell concentrate over 2 hours and 15 minutes with a dose of $5 \mathrm{ml} / \mathrm{kg}$ body weight. The post-transfusion vitals were stable, with post transfusion hemoglobin levels were $6.6 \mathrm{~g} / \mathrm{dl}$ at 24 hours after transfusion and $7.6 \mathrm{gm} / \mathrm{dl}$ on day $20^{\text {th }}$ when the patient was discharged from the hospital. A IgM antibody assay for Ebstein Bar virus and Mycoplasma Pneumonia was positive with IgM antibody detection for both Mycoplasma and Ebstein Bar virus. Patient showed a moderate degree of agglutination on the post-transfusion peripheral smear with hemogram showing a total count of $4.8 \times 10^{3} / \mathrm{microL}$ and a differential count suggestive of lymphocytosis and monocytosis respectively.

A clinical diagnosis at discharge on the day22 was Right sided pneumonia with pleural effusion (? Tubercular) with autoimmune Hemolytic Anaemia secondary to Ebstein Bar Virus and Mycoplasma infection.

\section{Discussions}

Clinically significant allo-antibodies are those that cause decreased survival of RBCs possessing the target antigen. ${ }^{[2]}$ These antibodies are typically IgG antibodies that react in the antihuman globulin phase (AHG) of the indirect antiglobulin testing. ${ }^{[2]}$ Cold agglutinin are the antibodies that react optimally at $3-4^{\circ} \mathrm{C}$ or at room temperature $\left(22^{\circ} \mathrm{C}\right.$ to

Table: 1 bBlood grouping of patient at $4^{\circ} ; 24^{\circ}$ and $37^{\circ}$ celsius.

\begin{tabular}{|c|c|c|c|c|c|c|c|c|c|}
\hline S.No & \begin{tabular}{|l} 
Temperature \\
Degree Celsius
\end{tabular} & $\begin{array}{l}\text { Antiserum } \\
\text { A }\end{array}$ & AntiserumB & AntiserumD & $\begin{array}{l}\text { Antiserum A1 } \\
\text { lectin }\end{array}$ & AntiserumH & $\begin{array}{l}\text { A cells } \\
\text { Pooled }\end{array}$ & $\begin{array}{l}\text { B cells } \\
\text { Pooled }\end{array}$ & $\begin{array}{l}\text { Cells } \\
\text { Pooled }\end{array}$ \\
\hline & & IgM Monoclonal & IgM Monoclonal & IgM Monoclonal & IgM Monoclonal & IgM Monoclonal & & & \\
\hline 1 & 4 & $\mathrm{O}$ & ++++ & ++ & O & + & ++++ & ++ & ++++ \\
\hline 2 & 24 & + & ++++ & ++ & + & ++ & +++ & + & + \\
\hline 3 & 37 & $\mathrm{O}$ & ++ & + & 0 & + & ++ & $+/ w$ & $+/ \mathrm{w}$ \\
\hline
\end{tabular}

TABLE 2: cross-match report of the patient with most compatible donor blood sample

\begin{tabular}{|c|c|c|c|c|c|c|}
\hline S.No & $\begin{array}{l}\text { Temperature } \\
\text { Medium }\end{array}$ & Auto control & Control 1 & Control 2 & $\begin{array}{l}\text { Major Cross } \\
\text { Match }\end{array}$ & $\begin{array}{l}\text { Minor Cross } \\
\text { Match }\end{array}$ \\
\hline & $\begin{array}{l}\text { Degree } \\
\text { Celsius }\end{array}$ & $\begin{array}{l}\text { Patient cell+ Patient } \\
\text { serum }\end{array}$ & $\begin{array}{l}\text { Patient cells and } \\
\text { Bovine serum albumin }\end{array}$ & $\begin{array}{l}\text { Patient serum } \\
\text { and Pooled cells }\end{array}$ & $\begin{array}{l}\text { Patient serum and } \\
\text { donor cells }\end{array}$ & $\begin{array}{l}\text { Patient cells and } \\
\text { donor serum }\end{array}$ \\
\hline 1. & $40 C$ & + & No Agglutination & ++ & + & Compatible \\
\hline 2. & $240 \mathrm{C}$ & + & No Agglutination & + & + & + \\
\hline 3. & $370 \mathrm{C}$ & $\begin{array}{l}\text { Negative (test- tube) } \\
\text { Microscopic } 1 \mathrm{w} \\
\text { agglutination }\end{array}$ & No Agglutination & + & Compatible & Compatible \\
\hline
\end{tabular}


$26^{\circ} \mathrm{C}$ ) with the saline suspended RBCs. ${ }^{[1,2]}$ These antibodies typically present in the old age as primary cold agglutinin disease or sometimes in childhood secondary to conditions like infectious mononucleosis. ${ }^{[1]}$

The antibody responsible for the hematological profile in a patient could have been IgG, IgM, a biphasic clinically significant antibody or both (IgG and $\operatorname{IgM}$ ).

A positive agglutination in the autologous control (patient cell reaction with patient serum) with microscopic clumping along with control cells (patient serum reaction with pooled B cells) in this un-transfused patient indicated auto and allo-antibodies collaborating with clinical diagnosis of cold-agglutinin disease or drug induced hemolytic anemia in this patient.Table 2.There was no history of blood transfusion; hence alloantibody due to previous transfusion was ruled out. Auto-agglutination was considered attributable to the patient illness or therapeutic intervention because the drop in hemoglobin/ hematocrit continued after the patient admission despite standard treatment.

The direct agglutination testing (DAT) was negative for this patient and antigen with no reactivity at Antihuman globulin (IgG) phase hypothetically were not reactive IgG/ complement components residing on the RBC surface. The Indirect AHG testing, between the patient serum and in-house pooled B cells (control 2) showed agglutination in the pre-antihuman globulin phase at $4^{\circ} \mathrm{C}, 24^{\circ} \mathrm{C}$ and $37^{\circ} \mathrm{C}$ signifying $\operatorname{IgM}$ antibody or both $\operatorname{IgM}+\operatorname{IgG}$ to be responsible for auto-agglutination in this patient, multiple antibodies of $\operatorname{IgM}$ and $\operatorname{IgG}$ type or a single antibody showing dosage effect. ${ }^{[2]}$ However maximum reaction in the control 2 (patient serum vs pooled cell of the same blood group) was seen at $4^{\circ} \mathrm{C}$. (Table 2). The patient's serum showing reactivity (agglutination) with the pooled cells at $4^{\circ} \mathrm{C}, 24^{\circ} \mathrm{C}$ and $37^{\circ} \mathrm{C}$ (reverse grouping of patient;Table 2) also indicated prominent cold antibodies or multiple antibodies capable of causing hemolysis at $37^{\circ} \mathrm{C}$ incubation (broad thermal reactivity). Table 2.

The reverse grouping of this patient EDTA sample, showed maximum reactivity at $4^{\circ} \mathrm{C}$, with pooled $\mathrm{O}$ blood group cells. Table 1. An agglutination of non A; non B antibody in this patient was hence considered responsible for the $\mathrm{O}$ cell agglutination in this patient. This is indicative of the IgM antibody in the patients serum to not-specific towards $\mathrm{RBC}$ antigenic site i.e independent of the antigenic site for the $\mathrm{ABO}$ blood group system. The grade of agglutination also decreased for the $\mathrm{O}$ cells from $4^{\circ} \mathrm{C}, 24^{\circ} \mathrm{C}$ and $37^{\circ} \mathrm{C}$ in that order respectively.(see Table 1 and 2 respectively).

The aberrant agglutination observed in the reverse blood grouping of this patient at different temperature ranges; with the panel of two donors utilized for the cross matching, and the control 2 reactivity of patient serum with pooled $\mathrm{B}$ cells showing agglutination in pre-antiglobulin phase suggested the antibody being of IgM type and of broad thermal range (reactive reverse group mismatch samples at $4^{\circ} \mathrm{C}$ and $24^{\circ} \mathrm{C}$ and $37^{\circ} \mathrm{C}$ of the patient with progressive decreasing reactivity).

A non-compatible cross-match with two donor RBC units showing agglutination, at the pre-AHG phase with the patient serum at $4^{\circ} \mathrm{C}$ and $24^{\circ} \mathrm{C}$ and 0 to $\mathrm{MF}$ (mixed field reaction) at $37^{\circ} \mathrm{C}$ (major/minor complete cross-match and reverse blood grouping) and a negative control 1(patient cells with Bovine serum albumin) and DAT of patient cells indicated the implicating antibody to be present in with patients serum with cells non-reactive with the donor serum or BSA control (compatible minor crossmatch, Table 2). The reverse grouping (patient serum with pooled $\mathrm{ABO}$ cells) in this case were non-reactive at $37^{\circ} \mathrm{C}$, indicating minor anti $\mathrm{A}$ antibodies (anti $\mathrm{A} 1$, $\mathrm{Ax}$ etc.) not to be responsible for auto-agglutination. ${ }^{1}$ (Table 1).

This antibody was weakly reactive $(1 \mathrm{w})$ at $37^{\circ} \mathrm{C}$ in the auto-control indicated an antigen on the $\mathrm{RBC}$ surface reacting to an auto-antibody capable of causing hemolysis at body temperature. The patient cells showed minimal or no reaction with the serum of same blood group at $37^{\circ} \mathrm{C}$ (minor cross-match with two different donors), Table 2 varifying the forward blood grouping of this patient from the commercial antiserum..

The red cell concentrate of the B positive blood group with minimal cross-match reactivity was hence transfused under close monitoring to this patient. Indirect anti-globulin testing in the compatible complete cross-match at $37^{\circ} \mathrm{C}$ was indicative of the loss of IgM activity at this temperature with no reactivity for the $\mathrm{IgG}$ antibody.The heat elution technique was inconclusive for the patient RBCs.

Antibody screening and identification,, auto-adsorption, homologous adsorption; elution techniques by the commercial reagents, antibody titration or monoclonal IgG only antiglobulin serum without the complement activity were not employed because of resource constrains and the primary objective of transfusing an antibody non-reactive, antigenic negative Red Cells to this patient.

The agglutination was visible grossly and microscopically and was distinguished from the rouleaux formation, causes of which range from altered fibrinogen concentration ,albumin to globulin ratio or recipients of high molecular weight plasma expanders such as dextran., The temperature of incubation and the duration of incubation were kept standard and standard operating procedures were approved 
by the blood bank after the consultation of standard reference literature. ${ }^{[1,3,5,6]}$

\section{Conclusion}

Cold Agglutinin patients can be managed in emergency situations with blood transfusions even without following the standard antibody identification protocol to transfuse antigen negative blood transfusion, however agglutinins having a broad temperature range can cause intravascular hemolysis, with a rapid drop in hemoglobin and hematocrit levels. The identification of cold auto-antibody or the temperature of optimum reactivity of cold auto-antibody hence is critical for blood transfusion of such patients in the absence of specific tools to phenotype the antigen and provide an antigen negative red cells for transfusion.

\section{Acknowledgements}

The Department of Transfusion Medicine would like to acknowledge the efforts of respected Medical Superintendent and Medical Record Department for making the case papers accessible to the Department acknowledges the clinician in-charge of the patient Dr Atul Jindal, Assistant Professor Department of Pediatrics for managing the clinical treatment of this patient and the Department of Biochemistry and Pathology, AIIMS Raipur for the Blood reports of this patient.

\section{Reference:}

1. Greer JP, Arber DA, Glader B, List AF, Means RT, Paraskevas $F$ et al. Wintrobe's clinical hematology: Thirteenth edition. Wolters Kluwer Health Adis (ESP), 2013. 2312

2. Denise M. Modern blood banking and transfusion practices. 5th ed. Philadelphia:FA Davis Company; 2005. Harmening; pp.158-165.

3. Chiaroni, J., Touinssi, M., Mazet, M., De Micco, P. and Ferrera, V. Adsorption of autoantibodies in the presence of LISS to detect alloantibodies underlying warm autoantibodies. Transfusion, 2003;43: 651-655.

4. Leger, R. M. and Garratty, G. Weakening or loss of antibody reactivity after prewarm technique. Transfusion, 2003;43: 1611-1614. doi:10.1046/j.1537-2995.2003.00563.x

5. Klein HG, David J. Anstee. Mollison's Blood Transfusion in Clinical Medicine, 12th Edition,; Wiley-Blackwell. 2013; 944

6. Saran RK. Transfusion medicine: technical manual; 2nd ed; Directorate General of Health Services, Ministry of Health and Family Welfare, Government of India, 2003: New Delhi : 2003; 432

*Corresponding author:

Dr Sankalp Sharma, Assistant Professor, Department of Transfusion Medicine and Blood Bank, AIIMS, GE Road, Tatibandh, Raipur, Chhattisgarh.492099, India E-mail: sunray2077@gmail.com

Date of Submission : 08.08.2016

Date of Acceptance : 21.11.2016

Financial or other Competing Interests: None.

Date of Publication : 19.02.2017 